\title{
Red to Purple? Changing Demographics and Party Change in Texas*
}

\author{
Juan Carlos Huerta \\ Texas A\&M University-Corpus Christi \\ juan.huerta@tamucc.edu; @CHuertaPhD \\ Beatriz Cuartas \\ National Nuclear Security Administration \\ beatriz.cuartas@nnsa.doe.gov; @BeatrizHCuartas
}

*Paper prepared for the Annual Meeting of the American Political Science Association, Sept. 1013, 2020. 


\begin{abstract}
In the 2018 U.S. Senate election in Texas Democrat Beto O'Rourke came within $2.5 \%$ of defeating Senator Ted Cruz. In the 2016 presidential election Hilary Clinton lost to Donald Trump by 9\%points. While this was a large loss, it was narrower than Barack Obama's 16\%-point loss in 2012. Do these results indicate the long-awaited party transformation in Texas has begun, or was it simply a case of a 2018 Democratic wave election?

The state's ethnic and racial minority groups (people of color [POC]) are now a majority of the population, and the non-Hispanic white population is aging and being replaced by a much smaller cohort of whites. Have the demographic changes that Texas has experienced primed Texas for change from Republican domination to competitive elections between Democrats and Republicans?

This research will examine party identification in Texas by investigating demographic data and political generations. Individual level survey data from 2009-through 2019 will be used to measure trends in party identification by POC and generational cohorts. The initial findings suggest that Texas may be entering a transition phase as older white Texans (a large and very Republican cohort) are replaced by younger whites who are less likely to identify as Republican and are a relatively small cohort. In addition, the growing POC population that is replacing the older white cohorts is also the most likely to identify as Democratic. Thus, the research indicates that change is coming to Texas, and this change will have national political implications.
\end{abstract}




\section{Red to Purple? Changing Demographics and Party Change in Texas}

\section{Introduction}

Lost in the fallout of the 2016 presidential election was the result from Texas -- Hillary Clinton lost the state by nine points. While it was a big loss, it was an improvement over Barack Obama's 16-point loss in 2012. During the 2018 midterm elections, in a campaign that drew national attention, Beto O'Rourke, the Democratic nominee for U.S. Senate in Texas, came much closer to unseating incumbent Republican Senator Ted Cruz than seemed possible in a state that has been solidly Republican (lost by $2.5 \%$ ). Although O'Rourke lost, Texas Democrats picked up 12 seats in the Texas House, two seats in the Texas Senate, two seats in the U.S. House, and came close to winning in several other statewide races.

Texas has been a solidly Republican state in presidential elections since 1980, and by 2002 the Executive and Legislative branches were both controlled by Republicans. Texas is also a large state with the $2^{\text {nd }}$ most electoral college votes and if it becomes competitive, can have a major impact on presidential elections and national campaign strategies. Thus, Texas politics has national political implications.

An explanation for the improved results from Democrats is the changing demographics in the state. The percentage of the population comprised of people of color (POC) is growing, especially among Latinos. There is an expectation that this will also lead to political change because Latinos and African Americans are more likely to identify as Democrats than Republicans. Asian Americans have also been trending towards the Democrats. Finally, the white population (GOP base) in Texas is aging, and being replaced by a much smaller cohort of whites.

Hence, Texas presents a good case study for studying realignments and how the state could be entering an era of competitive two-party competition, resulting in national political implications, including presidential elections. Our research suggests that the state's diversifying 
electorate and young people's lower levels of Republican identification appears to be weakening the GOP's grip on Texas.

\section{A Changing Lone Star State}

Texas is the $2^{\text {nd }}$ largest state in the USA by population and size, and the state's population and geography are both very diverse. The transformation from a Democratic state to a Republican state is a familiar pattern across the south (Lublin 2004; Osborne et al. 2011; Rogers 2016a). Texas largely followed this pattern, but Texas is distinct from other southern states because of the proportion of the population that is Latino (predominatedly Mexican American). To understand why TX may be at the cusp of becoming a purple state, there needs to be an understanding of the state's evolving demographics.

According to reports from the Texas Demographic Center, in 2000 47\% of Texans were people of color (POC) and 53\% non-Hispanic white. Among the 47\% POC, $32 \%$ are Hispanic (referred to as Latino in this study), $11 \%$ Black, and 3\% Asian. By 2017, the estimate was 58\% POC and $42 \%$ non-Hispanic white. The 2017 estimate for POC is $39 \%$ Hispanic, 12\% Black, and 5\% Asian (Valencia 2018). Texas is a majority-minority state with a growing Hispanic population and a shrinking white population, and this provides the context for understanding party change in TX.

[FIGURE 1 ABOUT HERE]

These changing demographics lead to comparisons to California. CA consistently supported Republican presidential candidates through the 1988 election and is now considered a solid Democratic state, and the changing demographics are what brought the change. Research has focused on the mobilizing impact of 1994's Proposition 187 and the impact it had on the growing Latino population and the changing demographics of the state (Barreto et al. 2005; Bowler et al. 2006; Hui et al. 2018; Korey and Lascher 2006; Monogan and Doctor 2017). With these demographic changes, one may then wonder why Texas is not a competitive state in presidential and statewide elections. Rogers provides a thorough analysis of why 
demographic change is not enough (2016). Waiting for demographic change, especially with the growing Latino population, to deliver for Democrats has not happened. With respects to Latinos, mobilization efforts have been ineffective. Even with the growing population of people of color, Democrats would still need at least 35 percent of the white vote to win statewide elections (Rogers 2016b).

\section{Literature Review}

\section{Party Identification and Party Change}

By 2002 Texas had become a solid Republican state. Osborne, Sears, and Valentino provide a framework for understanding how this party change occurs (2011). Their study focuses on cohort replacement and impressionable years. The concept is that the civil rights movement impacted young adult whites during their impressionable years to orient them towards the

Republican party. During this time period the Civil Rights movement, race emerged as a major issue cleavage in the US party system (Carmines and Stimson 1989). Eventually, these southern whites who were socialized as Republicans during their impressionable years, replaced older whites, who had been socialized as Democrats, in the electorate through a cohort generational replacement. At the same time, they found that all southern whites experienced a decline in Democratic identification for the 1960-2008 time period (Osborne et al. 2011). Their research helps us to understand how the south realigned, and this framework of can be used to understand current changes in Texas.

Party identification is one of the most important concepts in political science when understanding electoral and political behavior and attitudes. The classic The American Voter noted how party identification is stable and foundational in understanding national elections (Campbell et al. 1960). Since The American Voter, numerous studies have continued to examine the role of party identification in American politics (Green et al. 2002; Lewis-Beck 2008; Stonecash 2010). 
Partisanship has become increasingly important in American politics over the past 50 years as individuals increasingly view their opposing party and its candidates more negatively negative partisanship (Abramowitz and Webster 2018). This negative partisanship has been fueled as the party divide on race became more evident-especially during the Obama years. Thus, evidence that Democratic identification in TX is increasing is likely to lead to different electoral outcomes.

\section{Latinos, African Americans, and Asian Americans}

The three largest historically underrepresented groups in Texas are Latinos, African Americans, and Asian Americans. While many Latinos have traditionally identified as Democrats than Republicans (with the exception of Cuban Americans), there are still questions about whether Latinos will continue identifying as Democrats (Street et al. 2015). Street, Zepeda-Millán, and Jones-Correa investigated the impact of deportations during the Obama administration had on young US -born Latinos. They found when young Latinos learned about the deportation policies under the Obama administration that it led to an increase in negative views of the Democratic Party.

Does this suggest then that Latinos are likely to begin identifying as Republicans? The prospects are not optimistic. Research has found that stronger feelings of Latino identify lead to stronger identification with the Democratic Party. As Latinos are socialized politically, part of that socialization is learning about the parties and their connections to Latinos. These factors create an environment that will likely promote Democratic identification among Latinos (Cisneros 2017).

The Democratic party passed civil rights and voting rights legislation in the 1960 s and become the party most associated with civil rights. Issues of race and civil rights emerged as an issue cleavage that defined party identification (Carmines and Stimson 1989). A shared "linked fate" helps us to understand why African Americans are more likely to identify as Democrats (Dawson 1994). Additional work has examined African American partisanship to understand the 
strong connections to the Democratic party and whether this allegiance will endure (Gay 2013; Hajnal and Lee 2011; Philpot 2017).

Asian Americans are also increasingly identifying as Democrats. Research using social exclusion as a framework finds that Asian Americans are more likely to identify as Democrats because of feelings that the Republican party is more likely to exclude them from American society (Kuo et al. 2017). Furthermore, Kuo et al provide evidence indicating that the majority of Asian Americans develop a pan-Asian identity.

\section{Impressionable Years and Cohort replacement}

The Impressionable Years hypothesis provides a useful framework for the analyses (Osborne et al. 2011). The logic is that the same processes that led to Texas realigning as a Republican state are at work moving Texas away from a solid Republican state. According to the impressionable years hypothesis, during young adulthood (impressionable years) is when political cohorts form their party identification. Older white Texans acquired their party identification during the civil rights era. This is when the Republican party began to gain support among southern whites as the Democratic party became associated with civil rights. After the civil movement era there was a subsequent retrenchment of civil rights during the Reagan and Bush years. These events helped to cement Republican identification among young adult cohorts during this era.

Public opinion surveys have found that adults born after 1980 are more likely to identify as Democrats ("Wide Gender Gap, Growing Educational Divide in Voters' Party Identification" 2018). Those born after 1980 came of political age during the Obama years and the unpopularity of George W. Bush as the war in Iraq continued and the economy entered the Great Recession. The generation born from 1981-1996 is defined by the is often referred to as the Millennial generation by the Pew Research Center, and those born after 1996 as Generation Z ("Generation Z Looks a Lot Like Millennials on Key Social and Political Issues" 2019), though the 
precise dates defining the youngest cohort of Millennials is vague (Rouse and Ross 2018). In addition, the generations born after 1980 are very diverse and is more liberal on some social issues, such as support for same sex marriage ("Generation Z Looks a Lot Like Millennials on Key Social and Political Issues" 2019; Rouse and Ross 2018).

In summary, Texas realigned to a Republican state (as did southern states in general). This change was fueled by the changed to American political parties as issues of civil rights and race became a defining issue cleavage. With demographic and generational change, Texas may be on the cusp of becoming competitive as a growing population of Democratic leaning Latinos, African Americans, and Asian Americans replace an aging white population.

\section{Research Design}

\section{Civil Rights Cohorts}

Key to the current study are generational cohorts. The cohorts adopted for this analysis are based on civil rights generations (Osborne et al. 2011) because the civil rights movement was a defining issue at the time during impressionable years of the white realignment in the south (including Texas). Large generations of white Texans were socialized as Republican during this era. That era is over, and this large Republican cohort is being replaced by a smaller cohort of white Texans and POC that went through their impressionable years in different conditions.

Osborne, Sears, and Valentino used the following cohorts:

- $\quad$ Pre-Civil Rights Cohort - born in 1935 or before, entered electorate before 1957

- Civil Rights Cohort - born 1936-1947, entered electorate from 1957-1968

- Post-Civil Rights Cohort - born 1948-1962, entered electorate 1969-1980

- Racial Retrenchment - born 1963-1978, entered electorate 1981-1986

For this study, a "born 1979 or later" (entered electorate after 1986) cohort is added. This cohort is predominately Millennials and some Generation Z. 


\section{Data and Methodology}

The investigation begins with Texas public opinion surveys from 1995 and 2004. These are used to establish if Texas was following a similar pattern observed by Osborne, Sears, and Valentino with the cohorts of whites, and if that can explain how the Democratic party era in Texas ended. The 1995 data is from the National Opinion Survey of Crime and Justice, 1995 (Flanagan 1996). This dataset includes both a Texas sample and a national sample. For the purposes of this project, only the Texas sample (501 respondents) is used. Texas data from 2004 comes from the Survey of Texas Adults, 2004 (Musick 2005). The 2004 data has 1504 respondents.

University of Texas/Texas Tribune Polls (TX Poll) from 2009, 201 1, 2013, 2015, 2017, and 2019 are used for the analyses.' Three TX Polls are done per year (spring, summer, and fall) and are merged. The 2009 and 2011 Texas Polls had 800 respondents for each poll, except for June 2009 that had 924 respondents. Hence, merging the three 2009 polls results in 2524 respondents and 2011 has 2400 combined respondents. The 2013, 2015, 2017, and 2019 polls all include 1200 respondents per survey, yielding 3600 per year. The complete merging of polls yields 19,4324 respondents.

The investigation consists of line graph analyses of the 1995 and 2004 data to examine how Texas fits with the Osborne, Sears, and Nicholls findings. The investigation will then use the Osborne, Sears, and Nicholls framework with the 2009-2019 data and use both line graphs and linear regression.

\section{Variables}

Dependent. Four dependent variables are employed for the analyses. First is a 3-point party identification measure for the 1995 and 2004 surveys. Those identifying as Republicans are coded as 1, independents 2, and Democrats 3. The second, for the 2009-2019 Texas Polls is the 7point party identification measure. Party identification is coded as 1=strong Republican, 2=weak

\footnotetext{
${ }^{1}$ Polls are available at https://texaspolitics.utexas.edu/polling.
} 
Republican 3=Republican leaner, 4=independent, 5=Democrat leaner, 6=weak Democrat, and 7=strong Democrat. The third and fourth dependent variables measure ideology. The 1995 and 2004 surveys use a 3 -point measure with $1=$ conservative, $2=$ moderate, $3=$ liberal. The 2009-2019 surveys use the 7-point ideological self-placement, with 1=very conservative, $2=$ somewhat conservativ3, 3=lean conservative, 4=moderate/middle, 5=lean moderate, $6=$ somewhat liberal, 7=very liberal.

Independent. The key independent variable measures the age cohorts. Osborne, Sears, and Valentino's civil rights cohorts, based on the year the respondent was born, are used for the 1995/2004 analysis. The cohorts are those born 1935 or before (pre-civil rights, voting eligible before 1957), born 1936-1947 (civil rights, became voting eligible 1957-1968), born 1948-1962 (post-civil rights, became voting eligible from 1969-1980); and born 1963-1978 (racial retrenchment, became voting eligible 1981-1996). For the 1995/2004 analysis, the expectation is that the born 1935 or before cohort of whites will be the most Democratic of the white cohorts. No difference is expected among POC.

The cohorts are modified for the 2009-2019 analysis because by this point there are not many respondents remaining who were born 1935 or before, and there is a new cohort of those born 1979 or later. Thus, those born 1935 or before are combined with those born 1936-1947, and this revised cohort is those born 1947 or before (eligible electorate before 1969). An additional category is also created for those born 1979 or later (eligible electorate 1987 and later). The other categories remain the same. The expectation is that younger cohorts of whites are more likely to identify as Democrats while the oldest cohorts are most likely to identify as Republican. No difference is expected among POC.

Demographic Control Variables. Key to the analysis is controlling for whether the respondent is a person of color or white. Regrettably, none of the surveys used in this investigation contain 
suitable samples of Latinos, African Americans, and Asian Americans, Native Americans, Muslim Americans, to conduct analyses on the groups separately. Research included in the literature view indicates that Latinos, African Americans, and Asian Americans share enough characteristics as Democrats to justify including the three (plus all others who do not identify as white) one category that will be referred to as "person of color" (POC). Hence, the race/ethnicity variable is coded so those who responded to the race/ethnicity as white are coded as "0" and all other responses (except those who refused to answer) are categorized as POC and coded as "1." It is expected the POC will be more likely to identify as Democrats than whites.

Other demographic controls are female and education. Males are coded as " 0 " and females as "1." Education is coded as follows: no high school degree=0; high school graduate=2; some college=3; 2-year college degree=4; 4-year college degree=5; post graduate $=6$. The expectations for female and education are that females and those with more education are both more likely to identify as Democrats.

\section{Critical Test}

If the impressionable years hypothesis is correct, we would expect to see younger generations of whites identifying as more Democratic than older generations. POC are expected to identify as Democrat at higher rates than whites. Thus, as older generation of whites are replaced in the population, they are being replaced by folks who are more likely to identify as Democrats. Via this process, Texas has the potential to become more favorable for Democratic candidates.

\section{Findings}

\section{$1995 / 2004$}

The investigation begins with the 1995/2004 data. Mean PID (3 point) is analyzed by year via a line graph (Figure 2). Consistent with the Osborne, Sears, and Valentino work, the 
generation born 1935 or before has the highest Democratic mean in 1995. By 2004 the pre-civil rights cohort's mean PID declined, but was still the highest. The younger cohorts all have lower means that the generation born 1935 or before indicating increased levels of Republican identification, thus the born 1935 or before generation was being replaced by generations that were more Republican. Thus, the Figure 1 findings explain how Texas Democrats were still able to win a few statewide races in the 1994 general election, and also how the Republicans demonstrated dominance in 2004.

\section{[FIGURE 2 ABOUT HERE]}

Ideology findings for 1995/2004 are presented in Figure 3. Though the born 1935 or earlier cohort has the highest mean Democratic PID, this is also the most conservative cohort. Perhaps this explains why they also had a decline in mean Democratic PID from 1995-2004. The Republican party, especially during the Clinton years, became a more conservative party. It would make sense then, that self-identified conservative Texans would move to the Republican party. The 1995 survey has 500 respondents, so with the potential for large errors when dividing the sample, a comparison of POC/Whites is not conducted.

[FIGURE 3 ABOUT HERE]

\section{9-2019}

The next step of the investigation is analyzing the 2009-2019 surveys. This is done by tracking mean PID (7 point) and Ideology (7 point) by survey year, and cohorts on line graphs, and the results are presented in Figure 4A. The line graphs yield differences by cohort. As expected, the oldest cohort (born 1947 and earlier) is the most Republican and the youngest cohort (born 1979 or later) is the least Republican. Ideology (Figure 4B) shows a similar pattern with the oldest cohort with the lowest means scores (most conservative) and the youngest cohort the most liberal, and trending in a liberal direction.

[FIGURES 4A AND 4B ABOUT HERE] 
In summary, the line graph analyses demonstrate that younger cohorts of Texans are less Republican and less conservative than older generations of Texans. This provides initial support that a cohort replacement is happening in Texas, though it has not yet led to statewide Democratic victories.

\section{Multivariate Analyses}

The investigation now moves to regression analyses to more thoroughly evaluate the impressionable years hypothesis in TX from 2009-2019. This investigation will use the same research design as Osborne, Sears, and Valentino (2011). Linear regression models with party identification and political ideology are the dependent variables. The four categories of age cohorts are recoded into three dummy variables, with the "born 1947 or earlier" as the reference category (in the constant). Two demographic controls are included-female and education level.

In addition, cohort x study year interaction terms are including to "assess differential rates of change over time between cohorts" (Osborne et al. 2011). The year term is based on the study year, thus $2009=0,2011=1,2013=2,2015=3,2017=4$, and $2019=5$. The expectation is that the born 1979 and later X study year interaction will have a significant and positive effect, indicating that the cohort became more Democratic over the 2009-2019 time period, compared to the born 1947 or earlier cohort. The model is also run with ideology as the dependent variable. Separate analyses are conducted for whites and POC to avoid a confusing model with additional interactions.

Evidence that Texas is changing as a result of generational replacement and changing demographics is supported if the born 1979 or later generation of whites is becoming more Democratic over time and if POC are maintaining higher levels of Democratic identification over time and across cohorts. This will signify that the Republican base of older whites is being replaced by a population that is more favorable to Democrats. 
Party Identification -- White. The results of the linear regression of party identification are presented in Table 1. For the predicted means of whites, the born 1947 or earlier cohort is the least Democratic of white cohorts. This is represented by the constant coefficient of 2.481 . The born 1979 and later cohort of whites is the most Democratic of the white cohorts (coefficient of $\left..474^{* *}\right)$. Interestingly, the white cohort born between 1949-1962 is more Democratic than the oldest cohort $\left(B=.300^{* *}\right)$, while the 1963-1978 cohort of whites had an insignificant effect. Females and those with higher education are also more Democratic.

\section{[TABLE 1 ABOUT HERE]}

The attitude change findings (the interactions) reveals the two youngest cohorts of whites are becoming more Democratic (compared to the born 1947 or earlier cohort). Both the born 1963-1978 and born 1979 or later cohorts had increases in Democratic identification from 2009 to 2019. The findings signify that white Republicans are facing a generational change, with young whites more likely to identify as Democrats than older whites.

Party Identification -- POC. The regression evidence demonstrates POC are more likely to identify as Democrats than whites across all age cohorts. The constant of 4.836 (signifying mean PID) is two points higher than that for whites, with no statistically significant differences between age cohorts. The attitude change coefficient indicates that POC born 1947 or earlier cohort became more Democratic over the 2009-2019 time period, whereas the other cohorts did not experience change. Female POC are also more likely to identify as Democrats, while education is not having a significant effect. Hence, POC are consistently Democratic, and are not facing the same type of partisan generational replacement whites are experiencing.

Ideology - White. The born 1979 and later cohort is also least conservative cohort, while the born 1947 and earlier cohort is the most conservative. The born 1947 and earlier cohort has become more conservative during the 2009-2019 time period, whereas the 63-78 and 1979 and later 
cohorts became more liberal over time. Females and those with more education had positive and significant effects, indicating an increase in liberalism.

Ideology - POC. POC are more liberal than whites, and the born 1979 and later is the most liberal POC cohort. No POC cohort had a change in ideology during the 2009-2019 time period. Women and those with more education also have higher values of liberalism on the ideology measure.

The line graphs and regression results reveal that, among POC, all the cohorts, across each time period, are more Democratic than any white cohort. In 2019, the youngest cohort of POC is also the most Democratic. Additionally, the findings indicate the least Democratic cohort is older whites. As they leave the electorate, they are being replaced by younger whites, and they are the most Democratic cohort of whites.

\section{Discussion and Implications}

The key is to look at cohorts by white and POC, and line graphs help to complete the scene. Figure 5A visually demonstrates the differences between whites and POC on party identification. The results for whites indicate the oldest cohort (born 1947 and earlier) is the most Republican and the youngest cohort (born 1979 and later) is the least Republican. For POC, all

of the cohorts are more Democratic than any of the white cohorts, and by 2019 are clustering together with a mean of near five.

[FIGURES 5A ABOUT HERE]

Ideology results are in Figures 5B, and there is evidence the white cohorts born 1963-1978 and 1979 and later are both trending in a liberal direction and are the most liberal of the white cohorts. The liberalism of the youngest white cohort is comparable to that of POC. The oldest cohort of POC is the most conservative and the youngest most liberal.

[FIGURE 5B ABOUT HERE] 
The fact that Democratic identification is consistent across cohorts for POC, but that younger whites are less Republican than older whites, raises questions about the size of the cohorts, and if that is having an impact. Figure 6 presents a population pyramid for the Texas population by racial/ethnic groups for 2017. The age distribution for whites demonstrates there are many whites in the older groups, and then the population of whites shrinks as one moves to the younger age groups. The pyramids also make it clear, in comparison, among Hispanics the largest population is among the youngest and then the population numbers decline as one moves to older populations.

\section{[FIGURE 6 ABOUT HERE]}

Thus, a factor that has been overlooked in analyses of TX are the size of age cohorts by race and ethnicity. The TX Republican party's strength is among older whites, and this is a very large cohort. However, it is an aging population that is being replaced by a smaller cohort of whites who, while still Republican, identify at lower rates than older whites. Younger adults nationwide are more likely to identify as Democrats (Rouse and Ross 2018), and the evidence demonstrates it is also true in TX.

In addition, POC are a majority of younger Texans and they identify as Democrats. According to data obtained from The Demographic Evolution of the American Electorate, 19802060, in 2008 people of color were $44 \%$ of the voting eligible population in TX and estimated to be $51 \%$ in 2020 (Griffin et al. 2015). An examination for Hispanic turnout in TX from 2012-2016 finds Hispanic turnout increased by $30 \%$ while the percent of Hispanic population grew 15\% (Tallet 2018). This indicates the increase in Hispanic turnout outpaced the increase in Hispanic population growth, and this is a Democratic leaning group.

\section{Conclusion}

"'The Republican base of old white guys like me is dying — literally,' said Jerry Patterson a former Republican state Land Commissioner...." (Livingston and Samuels 2020). Patterson's 
observation is consistent with the analyses of public opinion and demographic data that demonstrate party change is occurring in Texas. The Texas GOP dominated Texas politics with support largely from generations of whites born 1962 and earlier. These older whites are being replaced in the electorate by a diverse cohort with a smaller number of whites who are more Democratic than older whites and POC who are overwhelmingly Democratic. Analyses of party in change in Texas have overlooked the smaller size of the young white population and that they are different politically from older whites. POC are overwhelmingly Democratic across generations, and are becoming a larger part of the TX electorate each year.

Thus, a shrinking older white population, a more Democratic identifying younger white population, and a growing POC population explain why Democrats have been making gains in TX since 2016 - there is a generational replacement occurring. The impressionable years hypothesis suggests that these younger whites are likely to remain more Democratic leaning than older whites as they age. Likewise, this is also true of POC. In addition, research on Generation Z (13-18 years old in 2018) suggests that share many similarities with Millennials on many social and political issues (Parker et al. 2019).

It is not inevitable that Texas becomes a competitive state or a Democratic state based on changing demographics. Nonetheless, these findings do help us understand how, since 2016 , Texas elections have become more competitive. Mobilization of the next generations of Texans is the key, and if Democrats can do this, the changes in Texas will change politics in the USA. 


\section{References}

Abramowitz, Alan I., and Steven W. Webster. 2018. "Negative Partisanship: Why Americans Dislike Parties But Behave Like Rabid Partisans." Political Psychology 39 (S1):1 19-35.

Barreto, Matt A., Ricardo Ramírez, and Nathan D. Woods. 2005. "Are Naturalized Voters Driving the California Latino Electorate? Measuring the Effect of IRCA Citizens on Latino Voting." Social Science Quarterly 86 (4):792-811.

Bowler, Shaun, Stephen P. Nicholson, and Gary M. Segura. 2006. "Earthquakes and Aftershocks: Race, Direct Democracy, and Partisan Change." American Journal of Political Science 50 (1):146-59.

Campbell, Angus, Philip Converse, Warren Miller, and Donald Stokes. 1960. The American Voter. New York: John Wiley and Son.

Carmines, Edward G., and James A. Stimson. 1989. Issue Evolution: Race and the Transformation of American Politics. Princeton: Princeton University Press.

Cisneros, Angel Saavedra. 2017. Latino Identity and Political Attitudes: Why Are Latinos Not Republican. New York: Palgrave Macmillan.

Dawson, Michael C. 1994. Behind the Mule: Race and Class in African American Politics. Princeton: Princeton University Press.

Flanagan, Timothy J., and Dennis R. Longmire. 1996. "National Opinion Survey of Crime and Justice, 1995.". Ann Arbor, Ml: Inter- university Consortium for Political and Social Research.

Gay, Claudine. 2013. "Knowledge Matters: Policy Cross-pressures and Black Partisanship." Political Behavior 36 (1):99-124.

"Generation Z Looks a Lot Like Millennials on Key Social and Political Issues." 2019.

Green, Donald P., Bradley Palmquist, and Eric Schickler. 2002. Partisan hearts and minds: political parties and the social identities of voters. London;New Haven, Conn;: Yale University Press.

Griffin, Rob, William H. Frey, and Ruy Teixeira. 2015. "The Demographic Evolution of the American Electorate, 1980-2060." Center for American Progress.

Hajnal, Zoltan L., and Taeku Lee. 2011 . "Leaving the Mule Behind: Independents and African American Partisanship." Princeton University Press.

Hui, Iris, Iris Hui, David O. Sears, and David O. Sears. 2018. "Reexamining the Effect of Racial Propositions on Latinos' Partisanship in California." Political Behavior 40 (1):149-74.

Korey, John L., and Edward L. Lascher. 2006. "Macropartisanship in California." The Public Opinion Quarterly 70 (1):48-65.

Kuo, Alexander, Neil Malhotra, and Cecilia Hyunjung Mo. 2017. "Social Exclusion and Political Identity: The Case of Asian American Partisanship." The Journal of Politics 79 (1):17-32.

Lewis-Beck, Michael S. 2008. The American voter revisited. Ann Arbor: University of Michigan Press.

Livingston, Abby, and Alex Samuels. 2020. "Polls suggest Joe Biden has a shot at winning Texas." In The Texas Tribune.

Lublin, David. 2004. The Republican South: Democratization and Partisan Change. Princeton, NJ: Princeton University Press.

Monogan, James E., and Austin C. Doctor. 2017. "Immigration Politics and Partisan Realignment: California, Texas, and the 1994 Election." State Politics \& Policy Quarterly 17 (1):3-23.

Musick, Marc A. 2005. "Survey of Texas Adults, 2004." Ann Arbor, Ml: Inter-university Consortium for Political and Social Research.

Osborne, Danny, David O. Sears, and Nicholas A. Valentino. 2011. "The End of the Solidly Democratic South: The Impressionable-Years Hypothesis." Political Psychology 32 (1):81107.

Parker, Kim, Nikki Graf, and Ruth Igielnik. 2019. "Generation Z Looks a Lot Like Millennials on Key Social and Political Issues." Pew Research Center. 
Philpot, Tasha S. 2017. Conservative but not Republican: the paradox of party identification and ideology among African Americans. New York, NY;Cambridge, United Kingdom;: Cambridge University Press.

Rogers, Mary Beth. 2016a. "How to Turn Texas Blve." In The Texas Observer.

- 2016b. Turning Texas Blue. New York, NY: St. Martin's Press.

Rouse, Stella M., and Ashley D. Ross. 2018. The Politics of Millennials.

: University of Michigan Press.

Stonecash, Jeffrey M. 2010. New directions in American political parties. Milton Park, Abingdon, Oxon;New York;: Routledge.

Street, Alex, Chris Zepeda-Millán, and Michael Jones-Correa. 2015. "Mass Deportations and the Future of Latino Partisanship." Social Science Quarterly 96 (2):540-52.

Tallet, Olivia P. 2018. "The Latino Vote: A Texas Tale of Growth and Misconceptions." Houston Chronicle: Web Edition, October 12, 2018.

Valencia, Lila. 2018. "Demographic Trends, Characteristics, and Projections for Texas."

"Wide Gender Gap, Growing Educational Divide in Voters' Party Identification." 2018. Pew Research Center. 
Figure 1.
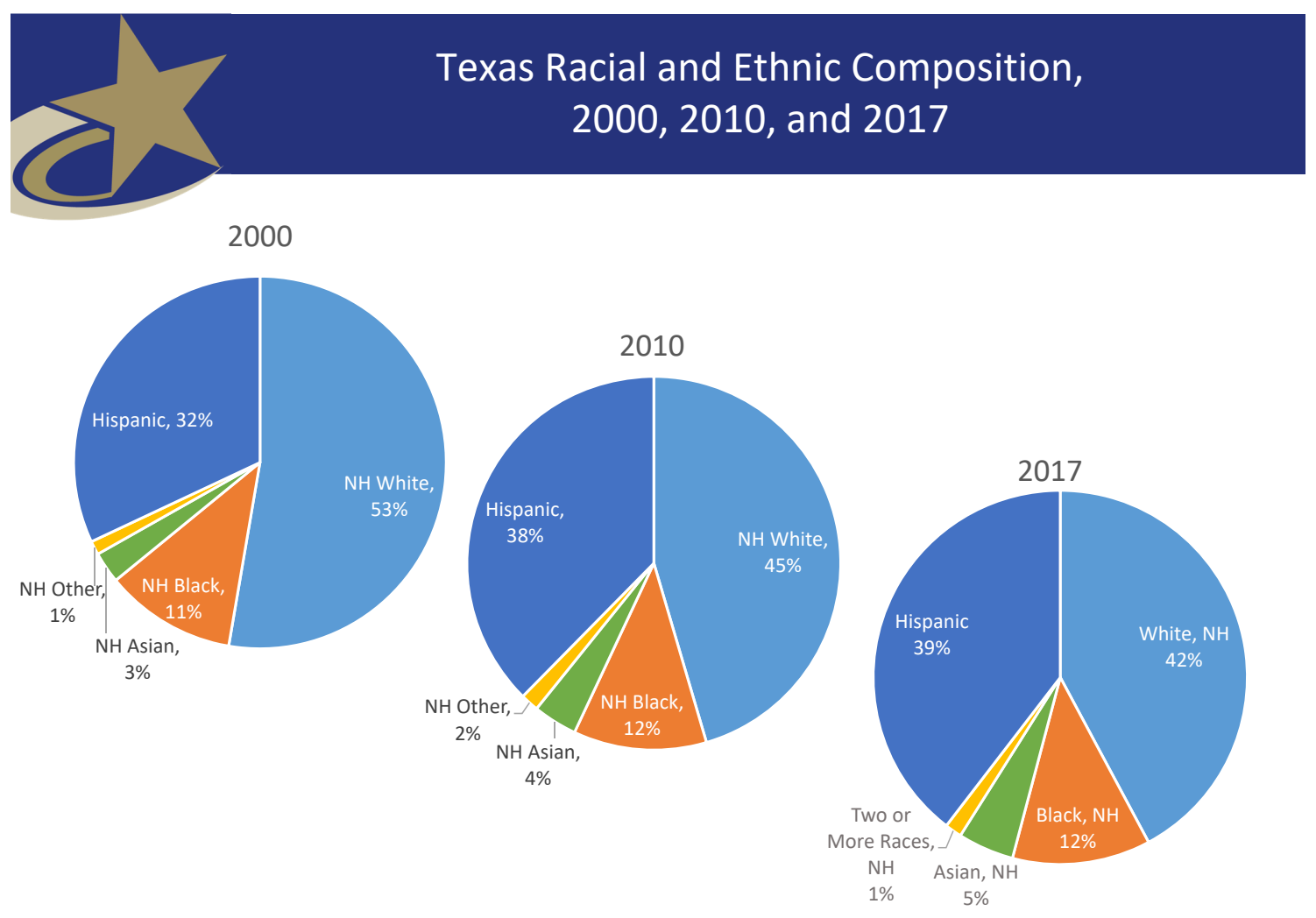

Source: Texas Demographic Trends, Characteristics, and Projections, Dr. Lila Valencia, Senior Demographer, Texas Demographic Center, The University of Texas at San Antonio 
Figure 2.

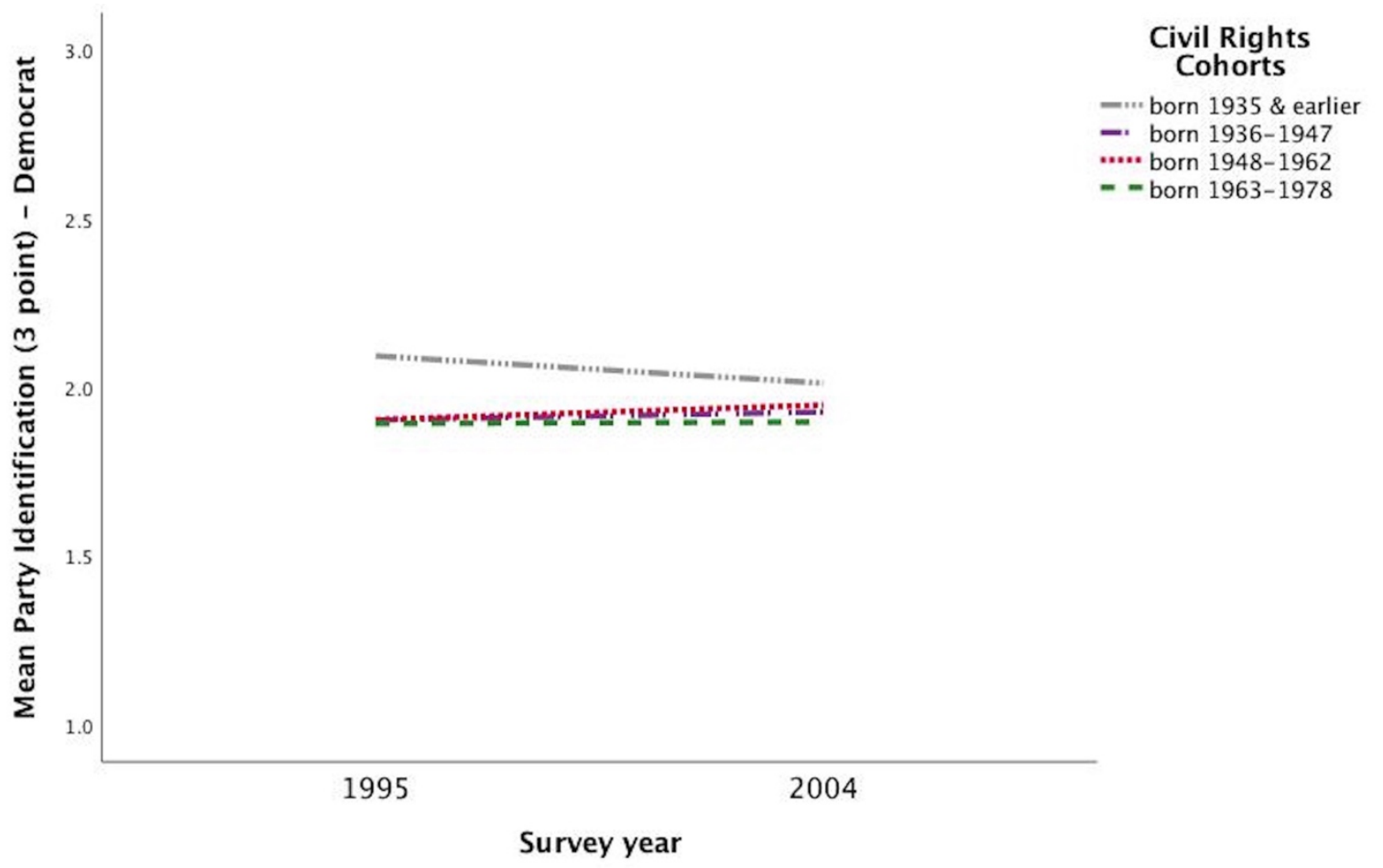


Figure 3.

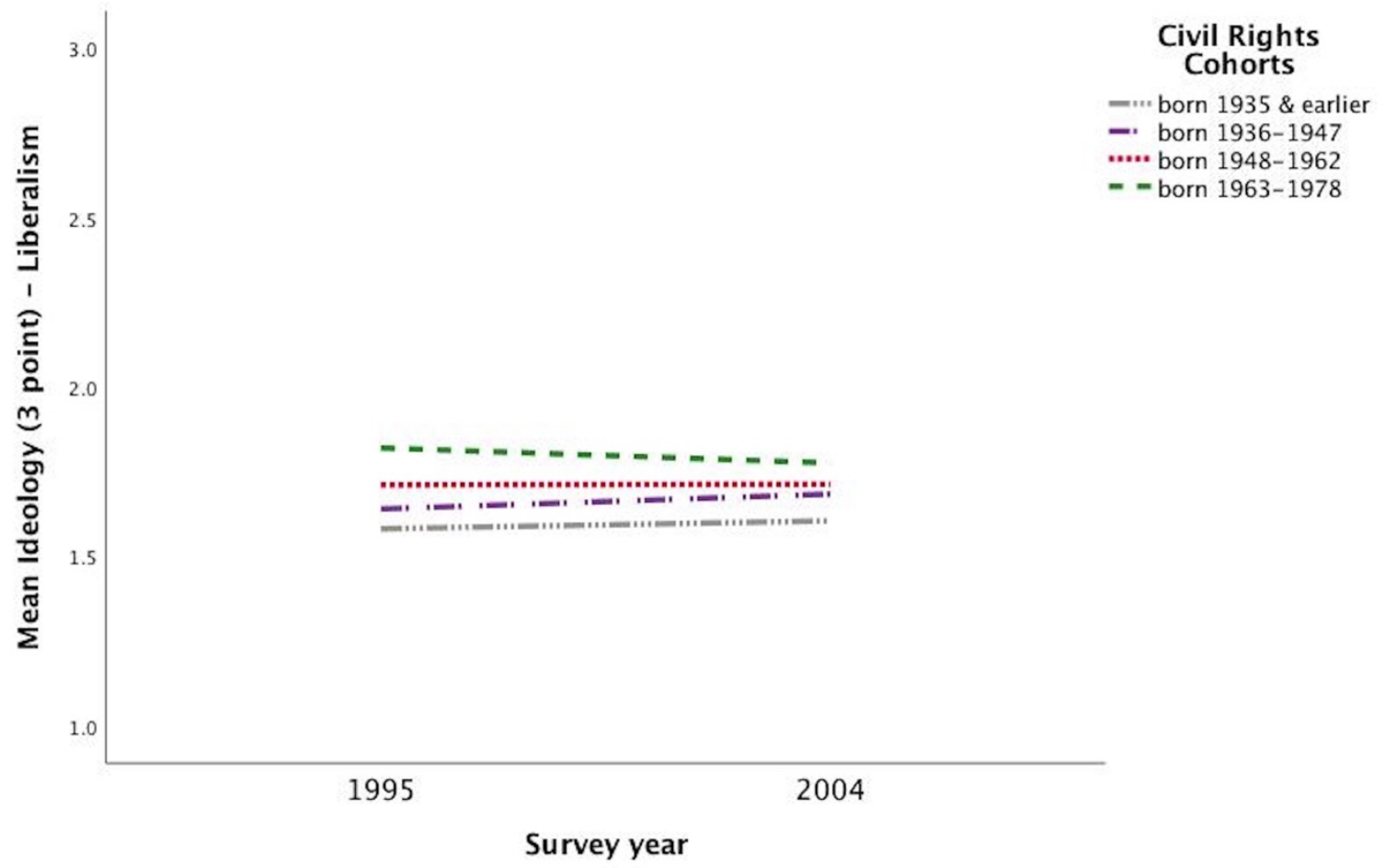


Figure 4A

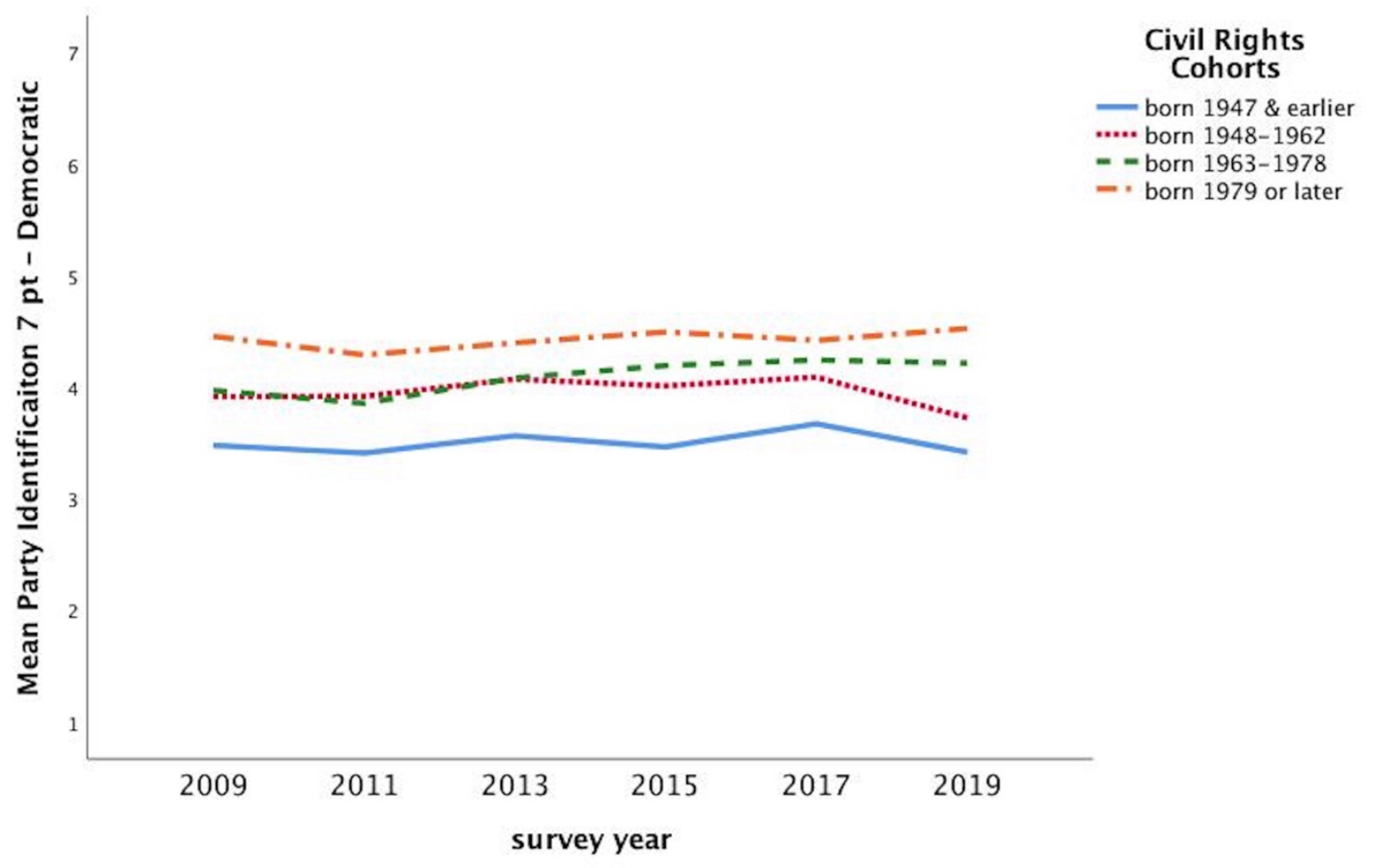


Figure 4B.

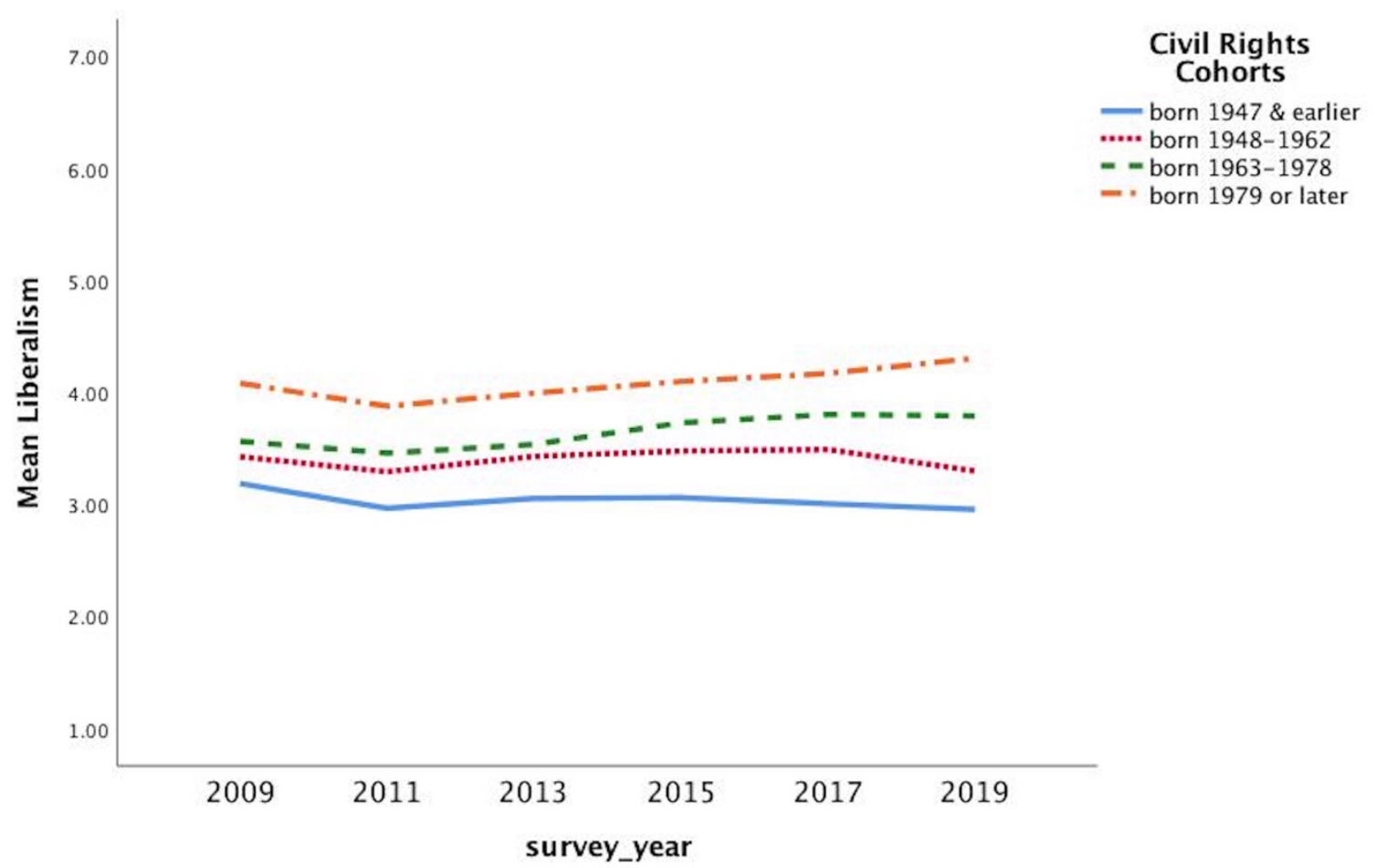


Figure 5A.

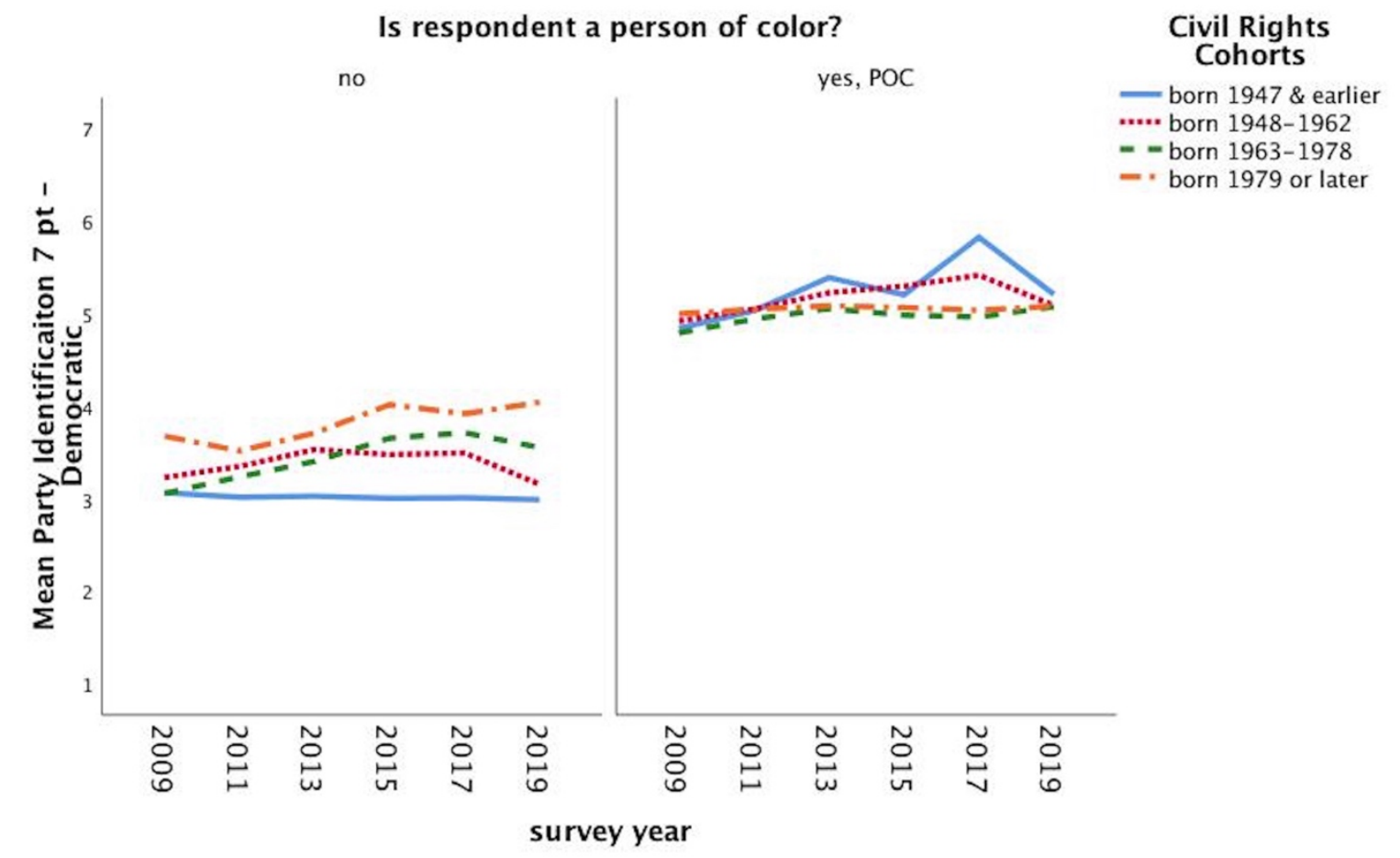


Figure 5B.

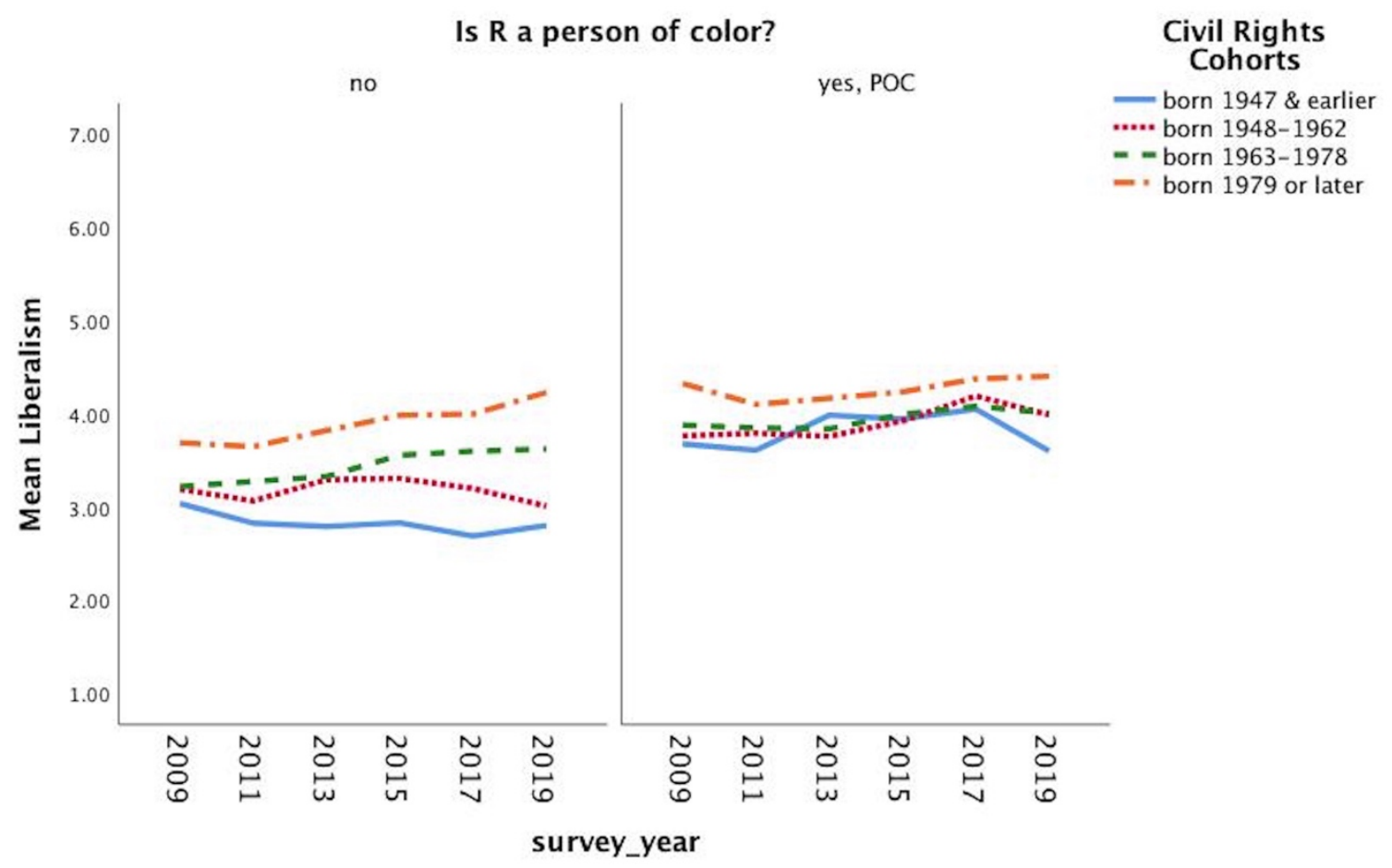


Figure 6.

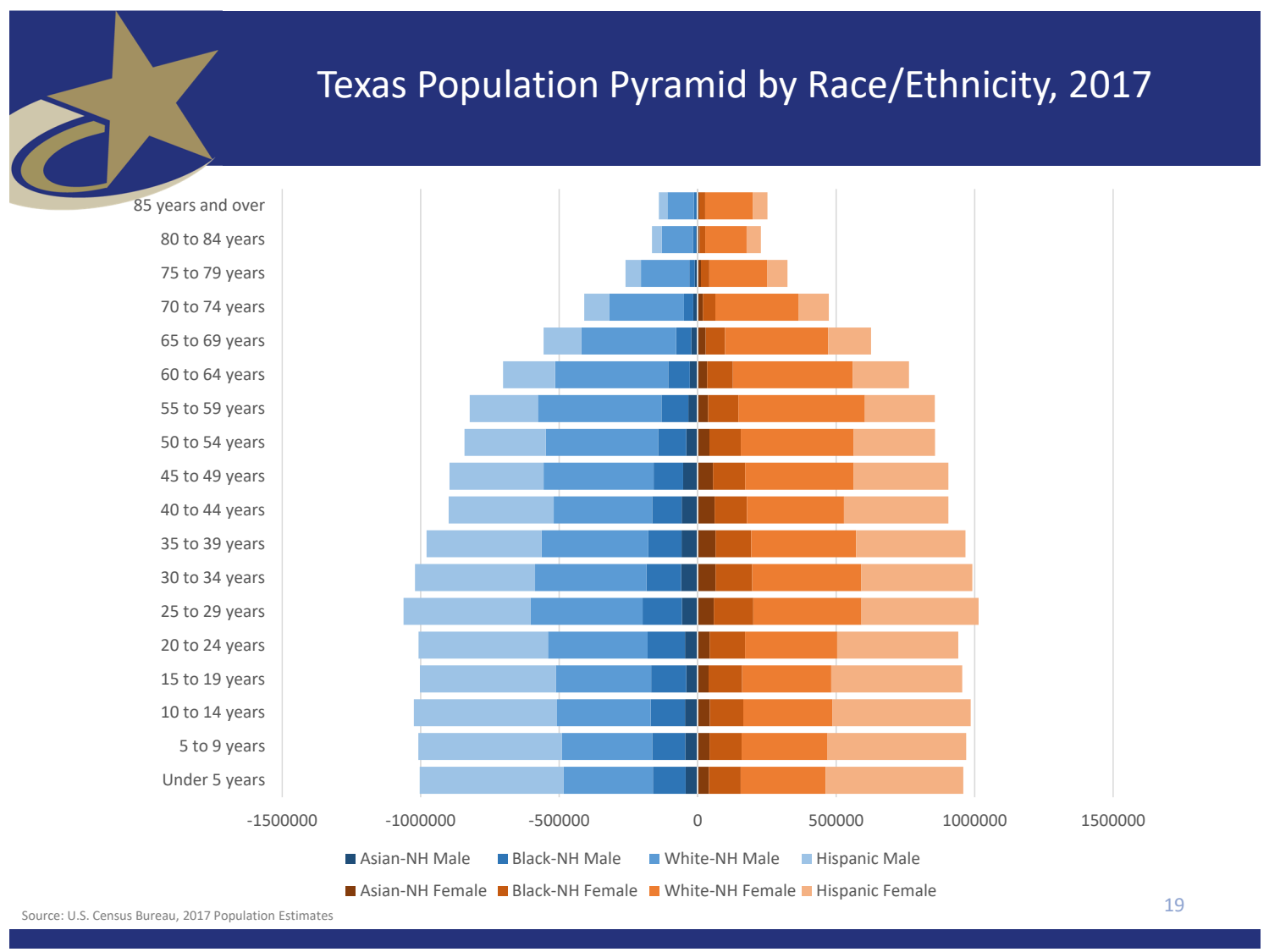


Table 1

\begin{tabular}{|c|c|c|c|c|}
\hline & \multicolumn{2}{|c|}{$\begin{array}{l}\text { Party } \\
\text { Identification }\end{array}$} & \multicolumn{2}{|c|}{ Political Ideology } \\
\hline & White & $\begin{array}{l}\text { Person } \\
\text { of Color }\end{array}$ & White & $\begin{array}{l}\text { Person } \\
\text { of Color }\end{array}$ \\
\hline & $\mathrm{B}$ & $\mathrm{B}$ & $\mathrm{B}$ & B \\
\hline \multicolumn{5}{|l|}{ Overall Level (predicted means) } \\
\hline Born 1947 or earlier (Constant) & $\begin{array}{l}2.481^{* *} \\
(.096)\end{array}$ & $\begin{array}{l}4.836^{* *} \\
(.158)\end{array}$ & $\begin{array}{l}2.355^{* *} \\
(.079)\end{array}$ & $\begin{array}{l}3.474^{* *} \\
(.126)\end{array}$ \\
\hline Born 1948-1962 & $\begin{array}{l}.300^{* *} \\
(.106)\end{array}$ & $\begin{array}{l}.005 \\
(.167)\end{array}$ & $\begin{array}{l}.249^{* *} \\
(.087)\end{array}$ & $\begin{array}{l}-.063 \\
(.133)\end{array}$ \\
\hline Born 1963-1978 & $\begin{array}{l}.046 \\
(.112)\end{array}$ & $\begin{array}{l}-.162 \\
(.165)\end{array}$ & $\begin{array}{l}.207^{*} \\
(.092)\end{array}$ & $\begin{array}{l}.042 \\
(.131)\end{array}$ \\
\hline Born 1979 \& later & $\begin{array}{l}.474^{* *} \\
(.135)\end{array}$ & $\begin{array}{l}.001 \\
(.173)\end{array}$ & $\begin{array}{l}.606^{* *} \\
(.111)\end{array}$ & $\begin{array}{l}.378^{* *} \\
(.137)\end{array}$ \\
\hline Is $\mathrm{R}$ female? & $\begin{array}{l}.232^{* *} \\
(.041)\end{array}$ & $\begin{array}{l}.480^{* *} \\
(.050)\end{array}$ & $\begin{array}{l}.336^{* *} \\
(.033)\end{array}$ & $\begin{array}{l}.174^{* *} \\
(.039)\end{array}$ \\
\hline $\begin{array}{l}\text { Education } \\
\text { Attitude Change (slopes) }\end{array}$ & $\begin{array}{l}.142^{* *} \\
(.014)\end{array}$ & $\begin{array}{l}-.030 \\
(.018)\end{array}$ & $\begin{array}{l}.129 * * \\
(.012)\end{array}$ & $\begin{array}{l}.064^{* *} \\
(.014)\end{array}$ \\
\hline Born 1947 or earlier (study year) & $\begin{array}{l}-.012 \\
(.027)\end{array}$ & $\begin{array}{l}.112^{*} \\
(.049)\end{array}$ & $\begin{array}{l}-.045^{*} \\
(.023\end{array}$ & $\begin{array}{l}.022 \\
(.039)\end{array}$ \\
\hline Born 1948-1962* study year & $\begin{array}{l}.003 \\
(.035)\end{array}$ & $\begin{array}{l}-.042 \\
(.057)\end{array}$ & $\begin{array}{l}.025 \\
(.029)\end{array}$ & $\begin{array}{l}.052 \\
(.045)\end{array}$ \\
\hline Born 1963-1978* study year & $\begin{array}{l}.121^{* *} \\
(.037)\end{array}$ & $\begin{array}{l}-.065 \\
(.055)\end{array}$ & $\begin{array}{l}.134^{* *} \\
(.030)\end{array}$ & $\begin{array}{l}.017 \\
(.044)\end{array}$ \\
\hline Born 1979 \& later * study year & $\begin{array}{l}.088^{*} \\
(.041)\end{array}$ & $\begin{array}{l}-.103 \\
(.056)\end{array}$ & $\begin{array}{l}.145^{* *} \\
(.033)\end{array}$ & $\begin{array}{l}.014 \\
(.045)\end{array}$ \\
\hline Model Summary & & & & \\
\hline Adjusted R-square & .029 & .017 & .063 & .019 \\
\hline SEE & 2.152 & 2.022 & 1.795 & 1.620 \\
\hline $\mathrm{N}$ & 11287 & 6814 & 11743 & 7131 \\
\hline
\end{tabular}

Note: Values represent unstandardized coefficients. Valves in parentheses are the corresponding standard errors.

High values represent pro-Democrat/Liberal responses

$* \mathrm{p}<.05, * *<.01$ 